\title{
AKTUALIZACIJA UČNIH VSEBIN Z VIDIKA VREDNOT PROSTORA IN PARTICIPACIJE JAVNOSTI V PROCESU PROSTORSKEGA PLANIRANJA
}

\author{
Simon Kušar \\ Oddelek za geografijo Filozofske fakultete Univerze v Ljubljani, \\ Aškerčeva 2, SI - I000 Ljubljana, Slovenija \\ e-mail: simon.kusar@ff.uni-lj.si
}

Izvirni znanstveni članek

COBISS 1.01

\section{Izvleček}

Ker je izobraževanje ključni element za doseganje ciljev trajnostnega (prostorskega) razvoja in za aktivno participacijo $v$ planerskem procesu, je potrebno te vsebine vključiti $v$ formalni izobraževalni sistem. V članku so predstavljene $\mathrm{z}$ vrednotami prostora in prostorskim načrtovanjem povezane vsebine, s katerimi se je dopolnjevalo obstoječe učne načrte izbranih predmetov na primarni in sekundarni ravni izobraževanja ob njihovi zadnji reformi leta 2007.

Ključne besede: trajnostni razvoj, vrednote prostora, kurikul, prostorsko planiranje, participacija javnosti.

\section{ACTUALIZATION OF CURRICULA WITH VALUES OF SPACE AND PARTICIPATION IN SPATIAL PLANNING PROCESS}

\begin{abstract}
Since education is a key element in achieving goals of sustainable (spatial) development and for successful public participation in the planning process, these topics should be incorporated into the formal educational system as well. The article presents topics discussing values of space and spatial planning with which selected curricula on the primary and secondary level of education were supplemented during their renewal in 2007.
\end{abstract}

Key words: sustainable development, values of space, curriculum, spatial planning, public participation. 


\section{UVOD}

Trajnostni razvoj, ki je postal razvojna paradigma Evropske unije in s tem tudi Republike Slovenije, postavlja pred vzgojnoizobraževalne ustanove nove izzive, saj je za njegovo doseganje ustrezno izobraženo prebivalstvo vitalnega pomena (Smrekar 2006). Okoljski steber trajnostnega razvoja, ki temelji na varovanju okolja, varčni rabi obnovljivih in neobnovljivih naravnh virov ter ohranjanju biotske raznovrstnosti, je v slovenskih šolah prisoten že vrsto let, kajti vzgoja »pobiranja papirčkov« je bila presežena s spodbujanjem razumevanja kompleksnosti ekoloških, naravovarstvenih in nekaterih za trajnostni razvoj pomembnih družbenih vsebin. Ekonomski (kakovosten gospodarski razvoj, ki upošteva omejitve okolja) in socialni steber (socialna kohezija, demokracija) trajnostnega razvoja sta prav tako vključena v izobraževalni vrednostni sistem. Trajnostni razvoj pa vsebuje tudi prostorski vidik, ki je ponavadi manj prisoten $\mathrm{v}$ kurikulih in posledično $\mathrm{v}$ zavesti ljudi, kar so pokazale tudi analize učnih programov v Sloveniji in tujini (Resnik Planinc 2006). Ta ugotovitev je bila izhodišče za pripravo novih prostorsko orientiranih vsebin, s katerimi bi bilo potrebno dopolniti kurikule izbranih predmetov. Predlagane vsebine zato poudarjajo prostorski vidik trajnostnega razvoja: prepoznavanje vrednot prostora ter ovir v prostoru, ki ovirajo kakovostno življenje sedanjim generacijam ali onemogočajo doseganje trajnostnega prostorskega razvoja prihodnjim generacijam (prostorske nevrednote). Zaradi velikega pomena sodelovanja prebivalcev pri uresničevanju trajnostnega prostorskega razvoja so bile vključene tudi vsebine, ki govorijo o možnostih za formalno in neformalno sodelovanje $\mathrm{v}$ procesu prostorskega planiranja.

\section{PROSTORSKO ORIENTIRANE VSEBINE: TRAJNOSTNI (PROSTORSKI) RAZVOJ, VREDNOTE PROSTORA IN PARTICIPACIJA JAVNOSTI V PLANERSKEM PROCESU}

Trajnostni razvoj ni enodimenzionalen koncept. Prvotno ozko razumevanje izraza v smislu zaščite oziroma varovanja naravnega okolja se je pozneje razširilo še na polje gospodarskega in socialnega razvoja. Zato se ob obravnavi trajnostnega razvoja ponavadi izpostavljajo trije stebri (okolje, družba in gospodarstvo), pri čemer je za doseganje trajnostnega razvoja potrebno usklajevati razvoj vseh treh stebrov.

V okviru tega konteksta prostor ponavadi ni posebej izpostavljen. Nekatere razlage trajnostnega razvoja ga vključujejo v polje okolja (glej npr. Plut 2005), medtem ko Evropske prostorske razvojne perspektive (2000) razumejo prostor kot vezni člen vseh treh stebrov. Prostor oziroma prostorske ureditve so namreč ključnega pomena za kakovostno življenje ljudi, vplivajo na enakost družbenih skupin ter so predpogoj za uspešen gospodarski razvoj. Delovanje vsakega posameznika je nenazadnje vedno »prostorsko«: vsi si želijo varne poti v šolo, urejeno infrastrukturo, primerno dostopnost do delovnega mesta in rekreacijskih območij, svojo hišo z vrtom ali stanovanje, ki naj bi bilo po možnosti varno pred poplavami ali porušitvijo, pozabiti pa se ne sme tudi na estetske vidike prostorskih ureditev. Trajnostni prostorski razvoj poudarja dejstvo, da je prostor omejena dobrina, s katero je potrebno modro ravnati, da bodo omogočene primerne (prostorske) možnosti tudi prihodnjim generacijam. 
Slika 1: Prostor kot vezni člen stebrov trajnostnega razvoja: družbe, gospodarstva in okolja Figure 1: Space as a link between pillars of sustainable devlopment: society, economy and environment

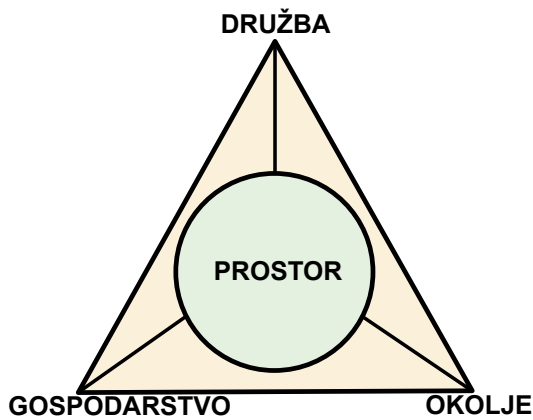

Vir: Evropske prostorske razvojne perspektive, 2000.

Odnos do prostora se izraža preko vrednot prostora (Demšar Mitrovič in ostali 2007). Vrednote prostora so sistem norm, vedenj, prepričanj, stališč, mnenj in dojemanj, ki vplivajo in usmerjajo odnose med posamezniki, prostorom in dejavnostmi v prostoru (Resnik Planinc 2006). Najpreprostejši način dojemanja vrednot prostora je preko opredelitve temeljnih elementov prostora (odprtega in grajenega), v katerem se pojavljajo vrednote. Ti elementi so neposredno ali posredno povezani $\mathrm{z}$ lastnostmi prostora: $\mathrm{s}$ fizičnimi lastnostmi in zaznavnimi kakovostmi, z materiali, iz katerih so zgrajeni, njihovim odnosom do okolja, njihovim preoblikovanjem in/ali stalnostjo, z načinom uporabe, $\mathrm{z}$ gospodarskimi procesi in podobno (Fridl in ostali 2007a).

Vrednote prostora so produkt človekove kreativnosti. Posamezni prostorski element zato sam po sebi še ni vrednota, je pa vrednota funkcija, ki jo opravlja za posameznika ali družbo in jo zato posameznik ali družba priznavata kot vrednoto (Demšar Mitrovič in ostali 2007). Vrednote so lahko individualne (zavedanje vsakega posameznika) ali družbene (veljajo za celotno skupnost). Družbene vrednote prostora so ponavadi zapisane v temeljnih strateških prostorskih dokumentih ali pa so elementi prostora, ki so spoznani za vrednote, vključeni $\mathrm{v}$ posebne sezname kulturnih in naravnih vrednot. Pri tem je potrebno upoštevati, da so vrednote odvisne od časa (niso stalne), kulture (kriteriji vrednotenja se spreminjajo v skladu z družbenimi spremembami), udeleženca (individualne ali družbene), obsega in načina opazovanja, namenov opazovalca in njegovega postavljanja prioritet (Fridl in ostali 2007a). Razumevanje prostorskih vrednot prebivalstvu omogoča uživati ne le boljše življenje, temveč soustvarjati varnejši, lepši in bolj razumen svet (Demšar Mitrovič in ostali 2007).

Obstaja več načinov kategoriziranja vrednot prostora. $Z$ vidika trajnostnega prostorskega razvoja je najprimernejša delitev na ekološke, ekonomske ter kulturne in družbene vrednote (Demšar Mitrovič in ostali 2007) (Preglednica 1). 


\section{Preglednica 1: Sistem vrednot prostora}

Table 1: The system of values of space

\section{Ekološke vrednote}

- $\quad$ varovanje in zaščita (genetska raznovrstnost, naravno okolje);

- učinkovita raba (energije in naravnih virov);

- $\quad$ upoštevanje nosilnosti okolja (stabilnost, prilagodljivost, obnovljivost)

\section{Ekonomske vrednote}

- $\quad$ bivanjske vrednote (prostor kot nosilec in okvir človekovega bivanja in delovanja);

- produkcijske vrednote (fiskalna vrednost, tržna vrednost, kmetijska pridelava, lov, turizem, itd.);

- $\quad$ neprodukcijske vrednote (doživljajske: pešačenje, čolnarjenje, fotografiranje, itd.)

\section{Kulturne in družbene vrednote}

- $\quad$ znanstvene vrednote (razumevanje prostora in njegovega razvoja);

- $\quad$ estetske vrednote (upoštevanje naravnih in kulturnih lepot ne glede na njihovo rabo);

- $\quad$ zgodovinske vrednote (lastno razumevanje s pomočjo razumevanja naše dediščine);

- kulturno simbolne vrednote (pomen naravnih in kulturnih značilnosti za oblikovanje identitete);

- $\quad$ arhitekturne vrednote (uporaba materialov, ustvarjalnost in razumevanje okolja);

- duhovne vrednote (pogled v lastno notranjost, ki ga navdihuje prostor)

Povzeto po: Demšar Mitrovič in ostali, 2007.

V razvitem svetu se čedalje bolj kaže potreba po bolj intenzivnem formalnem in neformalnem vključevanju prebivalcev v proces prostorskega planiranja (Urbanc in drugi 2004). $\mathrm{S}$ tem naj bi se izboljšalo razumevanje prostorskih posegov ter preprečilo netrajnostne oblike upravljanja s prostorom, kot so nedovoljeni posegi v prostor (odlaganje odpadkov izven urejenih odlagališč odpadkov, črne gradnje), hkrati pa naj bi se preprečilo tudi družbeno nesprejemljive oblike udejstvovanja $\mathrm{v}$ procesu urejanja prostora ali konfrontacijo $\mathrm{z}$ investitorji in formalnimi urejevalci prostora (nasprotovanje sprejetim odločitvam z izsiljevanjem, npr. z zapiranjem cest). Neformalno sodelovanje javnosti lahko zajema različne oblike (npr. delavnice, tribune, pogovore), ki presegajo v prostorski zakonodaji opredeljeno participacijo v planerskem procesu. Neformalno planiranje tako postaja čedalje pomembnejši mehanizem za načrtovanje prostorskih ureditev in za uspešno uresničitev dogovorjenih posegov v prostor, kar še posebej velja za lokalno raven. Pomembno pa je tudi to, da občani znajo spremljati delo svojih voditeljev in po potrebi preprečiti posege v prostor, ki bi trajno zmanjšali vrednote prostora.

Participacijo javnosti in pravico do obveščenosti zagotavljajo različni mednarodni dokumenti, med drugim tudi Aarhuška konvencija, ki omogoča posameznikom in organiziranim skupinam, da na podlagi načela demokratičnosti odigrajo pomembno vlogo pri uveljavljanju trajnostnega (prostorskega) razvoja (Aarhuška konvencija 2002). 
Vrednot prostora, načel urejanja prostora in sodelovanja v procesu urejanja prostora pa se je potrebno naučiti, si jih privzgojiti. Pri tem pa je zelo pomemben formalni sistem izobraževanja.

\section{3. ŠOLA IN VREDNOTE PROSTORA}

Pri izobraževanju o vrednotah prostora se je potrebno zavedati treh dejstev.

1. Šola je najpomembnejši medij za izboljšanje zavedanja o prostorsko orientiranih vsebinah. Zato je še toliko bolj pomembno, da so te vsebine prisotne v kurikulih. Priznati pa je potrebno, da vsebine s področja vrednot prostora, trajnostnega prostorskega razvoja in prostorskega planiranja $\mathrm{v}$ učnih načrtih do sedaj niso bile ustrezno zastopane, kar je dokazala tudi mednarodna raziskava v okviru Interregovega projekta RAVE Space (Interreg IIIB CADSES R.A.V.E. Space - Raising Awareness of Values of Space Through the Process of Education). Teme, kot so sistemi prostorskega planiranja in prostorski problemi (širjenje urbanih površin, degradirana območja, pomanjkanje prostora, ustrezna infrastrukturna opremljenost in dostopnost) so anketiranci ocenili kot najbolj pomanjkljivo prisotne vsebine v kurikulih (Resnik Planinc 2006).

2. Starši današnjih učencev se $v$ procesu svoje formalne in neformalne socializacije večinoma niso učili o vrednotah prostora. Zato največkrat nimajo zadostnega znanja o dejavnikih in procesih, ki gradijo sistem vrednot prostora. Zaradi nepoznavanja vsebine in pomena vrednot prostora lahko celo ogrozijo njihov obstoj, saj se pogosto odločajo v nasprotju z načeli njihovega ohranjanja ali pa jim pri svojem delovanju posvečajo premalo pozornosti, hkrati pa s temi vsebinami in problemi ne seznanijo svojih otrok.

3. Pri varovanju vrednot prostora ima zelo pomembno vlogo prostorsko planiranje, ki naj bi opredelilo takšne politike in orodja, da bi se vrednote prostora ne samo ohranjale ampak tudi obnavljale ali celo oblikovale nove. $\mathrm{V}$ tem procesu pa lahko ljudje dejavno sodelujejo v obliki formalne ali neformalne participacije. Največkrat jih od tega odvrača pomanjkanje znanja o možnostih in poteh, ki omogočajo dejavno udejstvovanje v planerskem procesu. Naloga šol je, da učence seznanijo z možnostmi udejanjanja njihovih interesov.

Končni cilj izobraževanja o prostorsko orientiranih vsebinah je, da bi se ljudje zavedali kompleksnosti prostorskih problemov, vrednot prostora, jih znali varovati, in spoznali možnosti lastne aktivne udeležbe, s katero lahko prispevajo k ohranjanju vrednot prostora ali preprečijo njihovo razvrednotenje.

Začeti pa je potrebno z mladimi - prihodnjimi upravljalci sveta in urejevalci prostora. Učencem je potrebno pokazati in z njimi odkrivati, kateri elementi v prostoru so vrednote in kateri omejitve, ki onemogočajo kakovostno življenje sedanjim in prihodnjim rodovom, razložiti jim je potrebno kompleksnost prostora, prav tako pa jim je potrebno predstaviti okvir, znotraj katerega lahko udejanjajo svoje interese. 


\section{VKLJUČEVANJE PROSTORSKO ORIENTIRANIH VSEBIN $\checkmark$ KURIKULE}

Spoznanje, da je potrebno prostorsko orientirane vsebine vključiti v kurikule, je sovpadlo s prenovo kurikulov, ki je potekalo v letu 2007. Zato so bile pripravljene vsebine, s katerimi naj bi se dopolnilo obstoječe učne načrte. Predlogi za dopolnitev kurikularnih vsebin so bili pripravljeni pri naslednjih predmetih: geografija, spoznavanje okolja, družba, naravoslovje in tehnika, naravoslovje, okoljska vzgoja, družboslovje za srednje poklicno izobraževanje ter vzgoja za trajnostni razvoj. Posebna pozornost je bila posvečena poučevanju prostorsko orientiranih vsebin v okviru predmeta geografija zaradi njenega kompleksnega razumevanja prostora.

Preglednica 2: S prostorsko orientiranimi vsebinami dopolnjeni kurikuli

Table 2: With spatially oriented topics supplemented subjects

\begin{tabular}{|l|l|}
\hline Predmet & Razred \\
\hline geografija & $\begin{array}{l}\text { vertikala }(6 .-9 . \text { razred OŠ, srednje strokovno izobraževanje, poklicno- } \\
\text { tehniško izobraževanje, splošna gimnazija) }\end{array}$ \\
\hline spoznavanje okolja & 1. - 3. razred OŠ \\
\hline družba & 4. - 5. razred OŠ \\
\hline naravoslovje in tehnika & 4. - 5. razred OŠ \\
\hline naravoslovje & $6-7$. razred OŠ \\
\hline okoljska vzgoja & za OŠ (vsa triletja) \\
\hline družboslovje & srednje poklicno izobraežvanje \\
\hline vzgoja za trajnostni razvoj & medpredmetno kurikularno področje - kroskurikularni učni načrt \\
\hline
\end{tabular}

Prostorsko orientirane vsebine so bile vključene tudi pri oblikovanju predvidene kvalifikacijske strukture v sklopu programa "varstva naravnih vrednot", ki ga je pripravljal konzorcij biotehniških šol.

\section{I Vsebine vključene v kurikule}

Osnovni nabor vsebin, ki bi morale biti prisotne v kurikulih, je nastal s pomočjo analize strateških razvojnih prostorskih dokumentov in z metodo »viharjenja možganov« na štirih organizacijah (Direktorat za prostor Ministrstva za okolje in prostor, Oddelek za geografijo Filozofske fakultete Univerze v Ljubljani, Geografski inštitut Antona Melika Znanstvenoraziskovalnega centra Slovenske akademije znanosti in umetnosti, Ljubljanski urbanistični zavod), ki aktivno sodelujejo v različnih fazah urejanja prostora. Iz prvotno zelo obširnega nabora idej so bili opredeljeni glavni tematski sklopi, ki so bili podrobneje razčlenjeni na posamezne vsebine in gesla (Fridl in drugi 2007a):

$\mathrm{V}$ prvem tematskem sklopu $\mathrm{z}$ delovnim imenom prostor so bili vključeni pojmi, ki so osnova za razumevanje prostora (npr. meja, površina, kompleksnost prostora, omejen- 
ost prostora), njegovih vrednot (delitev vrednot prostora na ekološke, ekonomske, kulturne, družbene in druge vrednote) in trajnostnega prostorskega razvoja.

$\mathrm{V}$ naslednjem tematskem sklopu poimenovanem poselitev so bila v ospredju naselja, pa tudi grajeno okolje na splošno in kulturna dediščina.

Obsežen tematski sklop je predstavljal infrastrukturo. V omenjeni tematski sklop so se poleg energetske, cestne in železniške infrastrukture uvrstile tudi sodobne komunikacijske poti ter območja in objekti namenjeni rekreaciji.

Sledil je tematski sklop pokrajina. V ta sklop so bile zajete vsebine, ki so se nanašale večinoma na neurbanizirani prostor. Pri tem ni šlo le za različne vrste rabe tal, ampak so bile vključene tudi s problemskim pristopom zaznamovane vsebine, kot so degradirana območja, racionalna raba tal, zavarovana območja in pokrajinska pestrost.

Brez upoštevanja prisotnosti človeka in njegovih dejavnosti preučevanje in načrtovanje prostora ni popolno. Človek je namreč del prostora in njegov sooblikovalec. V okviru tematskega sklopa človek - okolje in prostor so bile predvidene naslednje vsebine: mobilnost, odpadki, varstvo okolja ter vpliv človekovih dejavnosti na prostor. $Z$ omenjenimi temami naj bi učenci pridobili znanja o pomenu javnega prometa, ravnanja $\mathrm{z}$ odpadki ter pomenu zdrave prehrane in prostorskih sprememb, ki nastajajo pod vplivom globalizacije. Globalizacija v tem primeru ni razumljena zgolj kot gospodarski proces, ampak kot prostorski planerski izziv in priložnost.

Posameznik ni le del prostora, ampak tudi del družbe, zato je bil poseben tematski sklop namenjen družbenemu okolju. Za ustrezno ravnanje s prostorom je potrebno razumeti različne življenjske sloge in družbene prakse ter načine delovanja družbe (civilna družba, lokalna skupnost, državna uprava, javni interes, meddržavno, čezmejno in medregionalno sodelovanje).

Zadnji vsebinski sklop z imenom prostorsko načrtovanje je vključeval nekoliko zahtevnejši nabor vsebin povezanih s prostorskim planiranjem. Njihova vključitev v izobraževalni proces je nujna, saj se bodo lahko učenci le s temi znanji razvili v aktivne in kritične državljane ter imeli pomembno vlogo v planerskem procesu. V skladu s sodobno planersko teorijo se pri načrtovanju posegov v prostor teži k vse večji vključitvi posameznikov in skupin, ki izkazujejo interes za partnersko sodelovanje, v planerski proces. Zato je potrebno spoznati poklic planerja, nosilce urejanja prostora, kaj so konflikti interesov ter kako pridobiti podatke o stanju v prostoru.

Pregled obstoječih kurikulov je pokazal, da je veliko prostorsko orientiranih vsebin že vključenih v učne programe, potrebno je bilo le poudariti njihovo prostorsko razsežnost. Pri obravnavi odpadkov je bilo na primer potrebno izpostaviti tudi vsebine, ki se nanašajo na načrtovanje odlagališč odpadkov, dostopnost do odlagališč, urejanje ekoloških otokov za ločeno zbiranje odpadkov, ozaveščanje prebivalstva, vključevanje prebivalstva v načrtovanje odlagališč odpadkov in podobno. Največji primankljaj se je izkazal predvsem pri vsebinah povezanih s prostorskim planiranjem (Preglednica 3). Poudarjene so teme, povezane z vrednotami prostora, arhitekturnimi značilnostmi naselij, prostorskimi problemi, posledicami globalizacije, prekomejnim sodelovanjem in prostorskim planiranjem. 
Preglednica 3: Najpogostejši predlogi novih vsebin v kurikulih

Table 3: The most frequently proposed new topics in curricula

\begin{tabular}{|l|l|}
\hline Tematski sklop & Vsebina - gesla \\
\hline prostor & $\begin{array}{l}\text { vrednote prostora, omejenost prostora, kompleksnost prostora, trajnostni } \\
\text { prostorski razvoj }\end{array}$ \\
\hline poselitev & $\begin{array}{l}\text { tipologija naselij, prostorski vzorec poselitve, sistem centralnih naselij, } \\
\text { tipologija zgradb, arhitektura, gradbeni materiali, kakovost bivanja, zelene } \\
\text { površine, kulturna dediščina, kulturni spomeniki }\end{array}$ \\
\hline infrastruktura & $\begin{array}{l}\text { naravni viri (obnovljivi/neobnovljivi), prometna infrastruktura, javni } \\
\text { promet, mirujoči promet, infrastruktura za šport in rekreacijo }\end{array}$ \\
\hline pokrajina & $\begin{array}{l}\text { raba tal, zavarovana območja, degradirana območja, ogozdovanje, naravne } \\
\text { ujme (poplave, potresi, plazovi, usadi) }\end{array}$ \\
\hline človek - okolje in prostor & $\begin{array}{l}\text { odpadne vode, nevarni odpadki, ločeno zbiranje odpadkov, globalne } \\
\text { spremembe, vpliv prostorskih posegov }\end{array}$ \\
\hline družbeno okolje & $\begin{array}{l}\text { meddržavno, čezmejno in medregionalno sodelovanje, odgovornost } \\
\text { posameznika in skupnosti }\end{array}$ \\
\hline prostorsko načrtovanje & $\begin{array}{l}\text { sistem prostorskega planiranja, demokratičnost planiranja, participacija } \\
\text { javnosti, usklajevanje interesov }\end{array}$ \\
\hline
\end{tabular}

\subsection{Cilji v kurikulih}

Cilji, ki naj bi se jih doseglo pri izobraževanju za trajnostni prostorski razvoj, so povezani predvsem s širjenjem znanja o vrednotah prostora, razmišljanjem o prostorskih problemih in načinih njihovega reševanja, zavedanjem posledic različnega ravnanja $\mathrm{v}$ prostoru, razumevanjem prepletenosti in medsebojne odvisnosti dejavnosti $\mathrm{v}$ prostoru, razvijanjem odgovornega odnosa do prostora in podobno.

Izpostavljeni so bili predvsem naslednji cilji (Fridl in drugi 2007b):

- $\quad$ razumejo, da ima vsaka odločitev prostorske posledice;

- $\quad$ se zavedajo trajnih posledic posegov v prostor;

- ugotavljajo in vrednotijo posledice določenih posegov v prostor;

- $\quad$ spoznajo najbolj pereče prostorske probleme in predlagajo rešitve;

- $\quad$ spoznajo poklice, ki so povezani z urejanjem naravnega in grajenega prostora;

- razumejo pomen in vlogo prostorskega načrtovanja ter sodelovanja javnosti v postopkih sprejemanja odločitev o posegih v prostor;

- $\quad$ samostojno raziščejo varne poti v šolo za pešce in kolesarje ter načrtujejo izboljšave;

- dajejo pobude za urejanje okolice šole;

- razvijajo pozitiven odnos do lastne vloge pri oblikovanju prihodnjega razvoja. 
Predlagane vsebine in učni cilji so prilagojeni starosti učencev oziroma dijakov. V nižjih razredih osnovne šole so v ospredju vsebine povezane $\mathrm{z}$ zaznavanjem vrednot prostora $\mathrm{v}$ šoli in njeni ožji okolici. Pri njihovem evidentiranju se ne uporablja samo vid, ampak vsa čutila. Vrednot prostora namreč ni mogoče najti izključno s pomočjo vida, ampak je potrebno tudi prisluhniti, vonjati ter občutiti. V višjih razredih osnovne šole prevladuje problemski pristop, hkrati pa se učence intenzivneje seznanja z razumevanjem prostorskega planiranja. Učenje za aktivno participacijo v procesu načrtovanja prostora se lahko na primer izvaja s pomočjo posebnih delavnic oziroma seminarjev, v katerih se iščejo najustreznejši pristopi k ureditvi okolice šole, pri čemer naj bi se ohranjale zaznane vrednote prostora, "nevrednote" pa poskusile odpraviti (Kušar 2007). Predlagano je tudi sodelovanje s prostorskimi planerji na lokalni ravni. V srednje šole, posebno v učne programe gimnazij, naj bi se vključile tudi bolj zahtevne vsebine povezane $\mathrm{z}$ globalizacijo, sistemom prostorskega planiranja v Sloveniji ter Evropski uniji in podobno. Na vseh stopnjah se opozarja na pravice in dolžnosti, ki izhajajo iz večjega vključevanja javnosti v proces prostorskega načrtovanja.

\section{SKLEP}

V članku so bile predstavljene vsebine in cilji, ki so bili vključeni v obstoječe učne načrte za boljše razumevanje pomena prostorskega planiranja, vrednot prostora in trajnostnega prostorskega razvoja. Sedaj je mogoče pričakovati, da bodo učenci in dijaki več izvedeli o vrednotah prostora, trajnostnem prostorskem razvoju in prostorskem planiranju. Te vsebine jim bodo omogočile aktivnejše vključevanje v načrtovanje prostorskega razvoja, na kar pa bi bilo potrebno pripraviti tudi prostorske planerje, predvsem na lokalni ravni. Le tako bo lahko neformalno planiranje zaživelo kot način demokratičnega upravljanja s prostorom z ustrezno porazdelitvijo odgovornosti in pravic ter omogočilo lažje doseganje trajnostnega (prostorskega) razvoja.

Učenci in dijaki bodo ob pravilno zasnovanem pristopu k poučevanju prostorsko orientiranih vsebin lahko osvojili številne veščine, ki so za uresničevanje načel trajnostnega (prostorskega) razvoja izjemno pomembne (Fridl in drugi 2007a):

- $\quad$ analitično mišljenje in delo,

- konstruktivnost,

- zmožnost vrednotenja,

- razvoj kritičnega mišljenja in distance,

- sposobnost analiziranja danih primerov,

- kompleksen pogled na reševanje prostorskih problemov,

- strpnost v sporazumevanju,

- usklajevanje idej,

- sprejemanje kompromisov,

- sprejemanje odločitev in odgovornosti,

- $\quad$ pozitiven odnos do lastne vloge pri oblikovanju prihodnjega razvoja,

- razumevanje posledic vsakodnevnih dejanj,

- $\quad$ odgovorno odzivanje na pobude. 
Pri doseganju učnih ciljev in pri poučevanju novih vsebin je bil v pomoč učiteljem oblikovan poseben model izobraževanja, ki vključuje tudi terensko delo (več o tem: Fridl in drugi 2007b). Med rezultati Interregovega projekta RAVE Space (več o projektu: www. rave-space.org) pa je potrebno izpostaviti tudi posebne izobraževalne filme na temo vrednot prostora. Pripravljen je bil tudi komplet učil, ki ga je mogoče najti na spletnih straneh omenjenega mednarodnega projekta.

Teoretično zasnovo poučevanja prostorsko orientiranih vsebin je sedaj potrebno le še začeti uresničevati v okviru rednih ur (geografije), možnosti pa se kažejo tudi v okviru projektnih dni ter v centrih šolskih in obšolskih dejavnosti.

\section{Viri in literatura}

Aarhuška konvencija v Sloveniji: strokovna priporočila za implementacijo Konvencije o dostopu do informacij, udeležbi javnosti pri odločanju in dostopu do pravnega varstva v okoljskih zadevah. 2002. Regionalni center za okolje za srednjo in vzhodno Evropo. Ljubljana.

Evropske prostorsko razvojne perspektive. 2000. Ministrstvo za okolje in prostor. Ljubljana. Medmrežje: http://www.mop.gov.si/si/zakonodaja_in_dokumenti/mednarodni_dokumenti/ (28.09.2007).

Demšar Mitrovič, P., Resnik Planinc, T., Urbanc, M. 2007: Geografsko izobraževanje o vrednotah prostora za zagotavljanje trajnostnega razvoja. Geografija v šoli 16, 3. Ljubljana.

Fridl, J., Kušar, S., Resnik Planinc, T., Simoneti, M. 2007a: Vključevanje vrednot prostora $\mathrm{v}$ proces izobraževanja. Kurikul kot proces in razvoj: zbornik prispevkov posveta, Postojna, 17.-19.1.2007. Zavod Republike Slovenije za šolstvo. Ljubljana.

Fridl, J., Ilc, M., Kušar, S. 2007b: Uvajanje vsebin vrednot prostora in prostorskega načrtovanja v učni proces. Geografija v šoli 16, 3. Ljubljana.

Kušar, S. 2007: Šola in njena okolica kot poligon za poučevanje o vrednotah prostora. Geografski obzornik 54, 3-4. Ljubljana.

Plut, D. 2005: Teoretična in vsebinska zasnova trajnostno sonaravnega napredka. Dela Oddelka za geografijo 23. Ljubljana.

R.A.V.E Space. Medmrežje: http://www.rave-space.org (15.11.2007).

Resnik Planinc, T. 2006: Vrednote prostora kot integralni del izobraževanja. Geografski vestnik 78, 2. Ljubljana.

Smrekar, A. 2006: Zavest ljudi o pitni vodi. Založba ZRC. Ljubljana.

Urbanc, M., Printsmann, A., Palang, H., Skowronek, E., Woloszyn, W., Konkoly Gyuro, E. 2004: Comprehension of rapidly transforming landscapes of Central and Eastern Europe in the 20th century. Acta Geographica Slovenica 44, 2. Ljubljana. 


\section{ACTUALIZATION OF CURRICULA WITH VALUES OF SPACE AND PARTICIPATION IN SPATIAL PLANNING PROCESS}

\section{Summary}

Sustainable development is a key development paradigm in the European Union and therefore in Slovenia, as well. Its three dimensions (economy, society and environment) are well recognized. But there is also a spatial dimension of sustainable development, that is according to European Spatial Development Perspectives (2000) connecting all three pillars of sustainable development. But people are not aware of that dimension of sustainable development. Since the formal education is a key element in raising awareness of sustainability, the curricula should bring new knowledge about space related topics (sustainable spatial development, values of space, spatial planning) to pupils - future managers of the world. Sustainable spatial development highlights the fact, that space is an important unrenewable source, too. The individual or social relationship to space can best be represented through values of space. Namely, values of space are the system of norms, behaviour, beliefs and understandings that influence and guide behaviour between individuals, space and activities in space. The simplest way to understand values of space is through definition of spatial elements that have a special function or meaning to people. Values of space can be categorized into ecological, economic, cultural and social. According to sustainable development paradigm all individuals should be formally and informally included in different stages when preparing spatial plans. Public participation is needed to ensure preservation of values of space, to help solving spatial problems and to supervise interests of politicians that are often too narrow. Public participation would increase the individual responsibility for achieving sustainable spatial development, too.

When discussing about the role of education some facts need to be highlighted:

- school is the most important medium that can increase awareness of space related topics, therefore, they need to be fully incorporated into existing curricula;

- $\quad$ pupils' parents were not taught to protect the space, informed about the paradigm of sustainable spatial development and about values of space;

- $\quad$ spatial planning is one of the most important activities that influence on the quality of life; public participation is needed in that process, but people lack the knowledge of how to do it.

The aim of education on space related topics is that people would be aware of complexity of spatial problems, values of space and to be capable to collaborate in preparation of spatial plans through formal and informal participation.

In Slovenia, curricula of different subjects (geography, environmental education, sustainable development and society) were supplemented with space related topics during their renewal in 2007. Firstly, the list of all possible topics was prepared using brainstorming in selected organizations engaged in different phases of spatial planning and through the analysis of national strategic spatial development documents. Main thematic complexes were developed covering space (with values of space), the system of settlements, infrastructure, 
landscape, humans - environment and space, social environment and spatial planning. Many space related topics have already been in curricula, but they needed to be pointed out. However, some proposals for new topics were prepared about values of space, architectural characteristics of settlements, spatial problems, and spatial dimensions of globalization, crossborder cooperation and spatial planning.

Goals in curricula that should be achieved are connected mainly with new knowledge about values of space, spatial problems and ways of their suppression, behaviour in space, and development of responsible relationship to space.

All proposed goals and topics are adapted to age of pupils. But on all levels of education rights and obligations while managing the space are pointed out.

After formal adoption of new goals and topics in school curricula, their implementation should start. There has already been developed a special model of education that can be used while teaching space related topics. Results of Interreg IIIB CADSES project R.AV.E. Space (Raising Awareness of Values of Space) are bringing some instructions as well. This is going to be an effort on the long run therefore results can not be expected to be seen soon. 